\title{
A digitalização do simbólico \\ e o capitalismo cultural-digital: a expansão dos serviços culturais-digitais no Brasil
}

Elder P. Maia Alves**

Resumo: O capitalismo cultural-digital tem como núcleo o processo de digitalização do simbólico. Esse processo abriga quatro fenômenos interdependentes: (1) a consolidação da tecnologia do streaming; (2) a expansão global do uso dos dispositivos digitais móveis, especialmente os smartphones; (3) a convergência digital; (4) o advento e a profusão da Web 2.0, etapa da Internet na qual a maioria dos conteúdos é criada, distribuída, compartilhada e consumida pelos próprios usuários. As interfaces entre esses quatro fenômenos permitiram que as maiores corporações de tecnologias digitais do planeta (Google, Amazon, Facebook, Apple e Microsoft) também tenham se tornado grandes corporações de arte, cultura e entretenimento, construindo novos modelos de negócios - os serviços culturais-digitais, especialmente a oferta dos serviços por assinatura via streaming. Tendo em vista o cruzamento de diferentes dados quantitativos acerca desses fenômenos, este trabalho objetiva compreender a expansão dos serviços culturais-digitais no Brasil nos últimos dez anos.

Palavras-chave: Capitalismo cultural-digital. Digitalização do simbólico. Mercados culturais-digitais. Serviços culturais-digitais. Suportes digitais móveis.

\section{The digitalization of the symbolic and the cultural-digital capitalism: the expansion of cultural-digital services in Brazil}

Abstract: The cultural-digital capitalism has as its core the process of digitalization of the symbolic. This process harbors four interdependent phenomena: (1) consolidation of streaming technology; (2) the global expansion of the use of mobile digital devices, especially smartphones; (3) digital convergence; (4) the advent and profusion of Web 2.0, the Internet stage in which most of the content is created, distributed, shared and consumed by the users themselves. The interfaces between these four phenomena have allowed the world's largest digital technology corporations (Google, Amazon, Facebook, Apple and Microsoft) to become major art, culture and entertainment corporations, building new business models - cultural services, especially the provision of subscription services via streaming. Considering the cross-reference of different quantitative data about these phenomena, this paper intends to understand the expansion of cultural-digital services in Brazil in the last ten years.

Keywords: Digital-cultural capitalism. Digitalization of the symbolic. Cultural-digital markets. Cultural-digital services. Mobile digital media.

\footnotetext{
* Elder P. Maia Alves é professor associado I na Universidade Federal de Alagoas, Instituto de Ciências Sociais, Programa de Pós-Graduação em Sociologia (PPGS/ ICS/Ufal), Maceió, Alagoas, Brasil. Orcid: 0000 0003-4896-1962. <epmaia@hotmail. com>.
} 


\section{Introdução}

E ste trabalho tem como objeto o processo de expansão dos serviços culturais-digitais no Brasil. Nos últimos dez anos, os serviços culturais-digitais têm redefinido por completo os mercados culturais em todo o mundo. No entanto, para compreender as especificidades deste objeto é preciso alargar bastante o arco de mudanças sociológicas que enlaçam os principais responsáveis pela penetração dos serviços culturais-digitais no Brasil. Esse complexo arco pode ser capturado a partir do que denominamos de capitalismo cultural-digital e digitalização do simbólico. É por meio da mobilização dessas duas categorias de análises que pretendemos responder à pergunta que anima esta investigação: como e por que as principais corporações de tecnologia digital do mundo (Google, Amazon, Facebook, Apple e Microsoft - Gafam) também têm se tornado as principais empresas de arte, entretenimento e cultura e como esse processo vem ocorrendo no Brasil?

Para responder à pergunta mobilizada acima é necessário descrever com precisão o processo regular de aproximação entre o domínio simbólico-artístico-estético e o domínio econômico-comercial-tecnológico. A aproximação desses domínios, desde a segunda metade do século XIX, já vem ocorrendo. Com a consolidação e expansão dos processos de industrialização e urbanização e, em seu bojo, o advento da fotografia, do cinema e da publicidade recrudesceram o fluxo de imagens, signos e sons, instaurando conflitos com as linguagens artísticas consagradas, como a pintura, a literatura e o teatro. No entanto, como demonstram Walter Benjamin (1980) e Norbert Elias (1993), foi exatamente esse processo, de ordem socioeconômica, que permitiu a emersão de novas clivagens de consumidores (comerciantes burgueses ascendentes, profissionais liberais ascendentes e camadas urbanas médias) e, mediante o consumo de novos e antigos conteúdos artísticos e culturais, conferissem maior autonomia relativa para seus criadores (pintores, escritores, músicos, arquitetos, fotógrafos, entre outros) em face dos ditames exercidos pela Igreja Católica e as cortes absolutistas durante os séculos XVI, XVII e XVIII.

O processo descrito acima se intensificou na primeira metade do século XX, fazendo emergir diversos mercados culturais (televisivo, cinematográfico, fonográfico e publicitário) e novas formas de dominação empresarial e comercial no centro do capitalismo avançado. O recrudescimento dos processos socioeconômicos descritos por Benjamin e Elias na primeira metade do século XX fez eclodir o processo de industrialização do simbólico (Canclini, 2001), este, por sua vez, evidenciou a aproximação de longa duração entre o domínio simbólico-artístico-estético e o domínio econômico-comercial-tecnológico. Atentos a essas mudanças nos contornos 
do capitalismo avançado, Adorno e Horkheimer cunharam, na década de 1940, o conceito de indústria cultural para, entre outros aspectos, capturar tal aproximação; assim como Raymond Williams, já nos anos de 1960, cunhou a categoria de materialismo cultural para evidenciar a interpenetração entre infraestrutura (as condições materiais de produção econômicas e industriais) e superestrutura (os conteúdos simbólicos, religiosos, artísticos, políticos, jurídicos e filosóficos). Em outros termos, a clássica complementação dialética elaborada por Marx - ainda na passagem da primeira para segunda metade do século XIX - entre a essência e a aparência.

A aproximação e a interpenetração entre o domínio simbólico-artístico-estético e o domínio econômico-comercial-tecnológico ganhou uma inflexão definitiva entre as décadas de 1960 e 1970. As mudanças ocorridas nessas décadas e recrudescidas desde então foram decisivas para se compreender o advento e a profusão do capitalismo cultural-digital e do processo de digitalização do simbólico. Duas transformações foram assim capitais:

i. a emergência da sociedade pós-industrial de serviços; e

ii. a consolidação da economia do conhecimento.

Desde a década de 1960 e 1970, assistimos à transição de uma economia urbano-industrial nacional para uma economia global da informação, caracterizada pelo sociólogo Daniel Bell (1973) como as novas sociedades pós-industriais. Conforme constata Bell, em 1870 o emprego agrícola representava 47\% da força total de trabalho nos Estados Unidos. Um século após, o emprego agrícola representava apenas $3 \%$ do total da força de trabalho empregada. Durante o mesmo período, o emprego no setor de serviços saiu de $26 \%$ para $60 \%$ do total da força de trabalho empregada. Entre as décadas de 1920 e 1970, ocorreu uma redução substantiva no contingente de trabalhadores empregados na indústria extrativa (mineração e agricultura), saindo de 28,9\%, em 1920, para 4,5\%, em 1970. No decurso das décadas de 1980 e 1990 esse mesmo processo passou a ocorrer em diversos outros países. As séries históricas de países como o Brasil demonstram a redução paulatina da indústria na composição do Produto Interno Bruto (PIB). Por exemplo, entre 2000 e 2017 ocorreu um crescimento regular do valor adicionado pelo setor de serviços à economia brasileira. Nesse último ano, o setor de serviços correspondia a $75,2 \%$ do valor adicionado ao PIB brasileiro, ao passo que o setor industrial adicionou $21,4 \%$ e o setor agropecuário 3,4\%.

No caso brasileiro, o processo de expansão dos setores de serviços e da correspondente desindustrialização foi ainda acompanhado por um contínuo déficit tecnológico. A fusão entre os investimentos em dispositivos tecnológicos, processos de 
inovação, agregação de valor aos serviços de elevado capital humano, e, por fim, a proteção jurídico-comercial (copyright) associada a tais bens, produtos e serviços produziu um elevado déficit na balança de pagamento das atividades econômicas que envolvem alta, média-alta, média-baixa e baixa intensidade tecnológica. De acordo com o Instituto de Pesquisa Econômica Aplicada (Ipea), entre 1996 e 2011 o Valor de Transformação Industrial (VIT) na economia brasileira sofreu sucessivas reduções. Este indicador mensura o nível de participação da transformação industrial a partir do grau de intensidade tecnológica: alta, média-alta, média-baixa e baixa.

Entre 1996 e 2011, os setores de alta intensidade tecnológica reduziram a sua participação de $8,8 \%$ para 5,5\% do VIT existente na economia brasileira (Ipea, 2017). Por outro lado, os setores de média-baixa tecnologia aumentaram a sua participação no VIT de $28,5 \%$ para 33,4\%. Associado a este processo, ocorreu uma redução substancial da indústria de transformação no saldo da balança comercial brasileira entre 2007 e 2013, saindo de um superávit de US\$22,2 bilhões para um déficit de US\$ 53,7 bilhões. Esse déficit resultou do aumento regular de diversos déficits contínuos nos setores de alta e média intensidade tecnológica desde 1996. Em 2013, o Brasil registrou um déficit comercial nos setores de alta intensidade tecnológica de US\$ 31,98 bilhões, no ano 2000 esse déficit foi de US\$ 3,67 bilhões; no que tange aos setores de média-alta intensidade tecnológica, o déficit foi de US\$ 55,44 bilhões, no ano 2000 esse déficit foi de apenas US\$ 7,68 bilhões. A quase totalidade da economia do conhecimento é composta por setores de alta e média-alta intensidade tecnológica, como os componentes computacionais, os softwares, os dispositivos digitais de tecnologia móvel, como os smartphones, a computação em nuvem, a Internet das coisas, a inteligência artificial, os serviços de conteúdos em pesquisa, desenvolvimento, educação, comunicação, arte, entretenimento e cultura.

A seminal análise de Castells (2009) sobre a sociedade em rede reforça as interpretações sugeridas por Bell. Desde as décadas de 1980 e 1990, o conhecimento, materializado em serviços e produtos, tornou-se um ativo imprescindível. A partir do início da década de 1990, os governos das mais poderosas economias do globo passam a carrear recursos crescentes para o financiamento das atividades de pesquisa e desenvolvimento que possam resultar em ganhos de valor econômico. Destacam-se nesse processo países como o Reino Unido, o Japão, a Coreia do Sul, os Estados Unidos, a China e a Alemanha. Entre os anos de 2000 e 2013, os Estados Unidos, a Alemanha e o Reino Unido elevaram paulatinamente os percentuais de seus PIBs para o financiamento de pesquisa e desenvolvimento. Os investimentos com pesquisa e desenvolvimento alcançaram, em 2013, o percentual de 2,1\% 
do PIB chinês, o que significou, em valores nominais, aproximadamente US\$ 24 bilhões. Não por acaso, as três principais economias do mundo (Estados Unidos, China e Japão) também são a que mais possuíam patentes, direitos de propriedade intelectual e copyright.

Concomitantemente ao desenvolvimento da economia global do conhecimento ocorreu o processo de digitalização de uma parte expressiva das atividades de serviços de pesquisa, informação, comunicação, conhecimento, lazer, entretenimento, arte e cultura. A digitalização - especialmente o que definimos como digitalização do simbólico (Alves, 2016) - aproximou, definitivamente, as interfaces entre arte, tecnologia, cultura, inovação e desenvolvimento ou, em outros termos, permitiu a consolidação definitiva de um novo amálgama entre o domínio simbólico-estético-artístico e o domínio econômico-comercial-tecnológico. Chamamos esse amálgama de capitalismo cultural-digital.

\section{A transformação das principais corporações de tecnologia digital em empresas de arte, cultura e entretenimento}

Antes de definir e fazer uso analítico das categorias de industrialização do simbólico e de capitalismo cultural-digital, é necessário assinalar que a consolidação das sociedades pós-industriais de serviços e a expansão das economias do conhecimento resultaram numa diferenciação bastante acentuada das economias contemporâneas. No centro dessa diferenciação repousa o papel econômico da Internet. É somente diante da descrição precisa de tal diferenciação que se torna possível situar o processo de digitalização do simbólico e o núcleo do capitalismo cultural digital, qual seja, o advento e a intensa expansão dos serviços culturais-digitais, criados e modelados pelas cinco maiores corporações de tecnologia digital do planeta, que também são as maiores empresas existentes no mundo - Google, Amazon, Facebook, Apple e Microsoft (Gafam). Entre 1998 e 2018, a expansão econômica e cultural da rede mundial de computadores resultou na seguinte diferenciação:

i. no primeiro e mais abrangente círculo concêntrico está a grande e multifacetada economia de serviços global (que abarca serviços de bem-estar, beleza, segurança, saúde, alimentação, moradia, lazer, arte, cultura, entretenimento, turismo, entre tantos outros);

ii. em um segundo círculo situam-se os mercados de bens simbólicos (audiovisual, musical, editorial, de artes cênicas, artes visuais, patrimônio, gastronomia, moda, entre outros); 
iii. num terceiro círculo está o e-commerce (atividade de comercialização de produtos, mercadorias e serviços por meio dos sites e plataformas digitais, cujo crescimento superou todas as expectativas nos últimos dez anos);

iv. no quarto círculo se situa a economia digital (composta por todas as atividades que mantêm vínculos e mediações com a Internet, monopolizada por poucas corporações globais e as plataformas que lideraram a chamada inovação disruptiva);

v. no último círculo encontram-se os serviços culturais-digitais (atividades de produção, distribuição e consumo de conteúdos artístico-culturais por meio de plataformas especializadas em serviços de streaming, tais quais Netflix, Amazon Prime Video, Apple Music, Spotify, Deezer, Twitch, entre muitos outros).

Os dois primeiros círculos existem na dimensão off-line, já os últimos três exigem a conectividade on-line.

FIGURA 1

DIFERENCIAÇÃO DA ECONOMIA GLOBAL CONTEMPORÂNEA

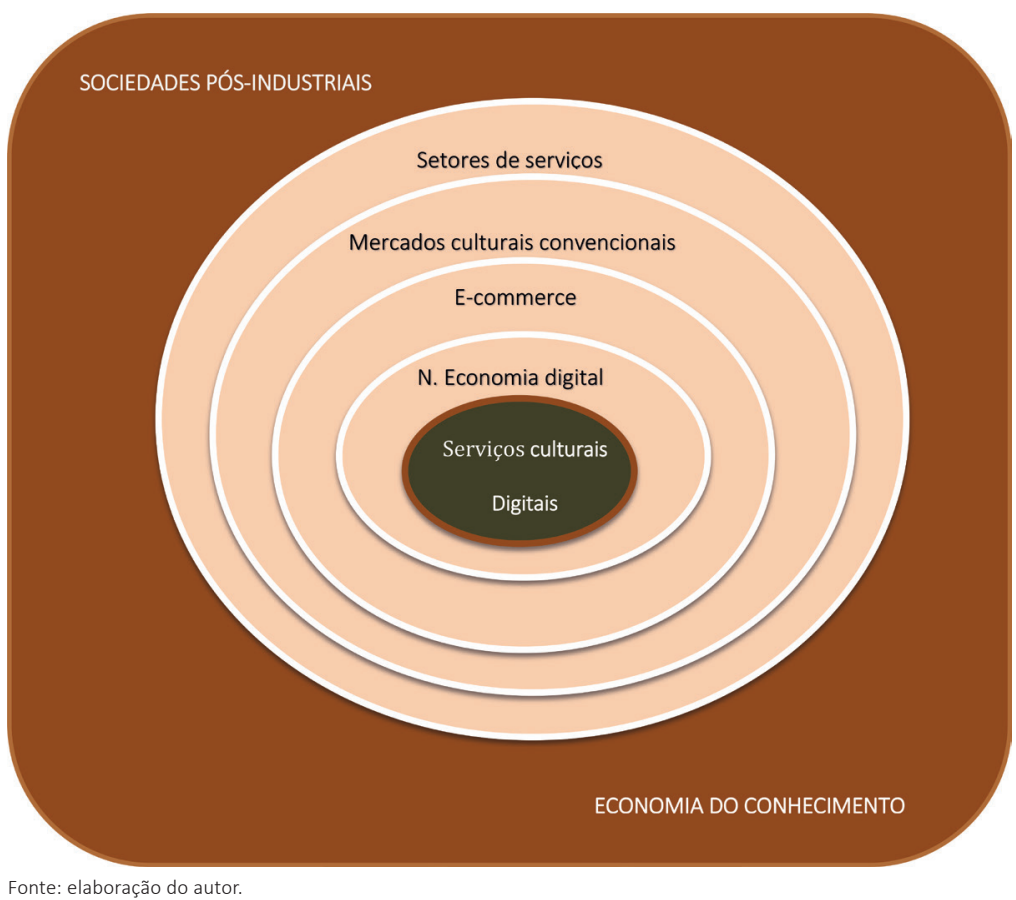


Em 2008, 23\% de toda a população do globo tinham acesso regular à Internet. Em 2016, oito anos depois, esse mesmo percentual se elevou para 46\%, um crescimento de exatos $100 \%$. Ainda em 2008, 61\% da população dos países desenvolvidos tinham acesso regular à Internet, percentual que aumentou para 80\% em 2016. No que tange aos países em desenvolvimento, $14 \%$ de toda a sua população tinham acesso regular à Internet, número que chegou a 39\% em 2016. O crescimento brasileiro durante esse período também foi bastante acentuado, saindo de $34 \%$ do total da população, em 2008, para 61\%, em 2016. No caso dos países menos desenvolvidos, o acesso à Internet saiu de 2\% da sua população, em 2008, para 16\%, em 2016 (CGI-BR, 2017). Os dados evidenciam dois aspectos:

i. uma intensa expansão do acesso à Internet, em todo o mundo;

ii. a existência de uma severa assimetria entre as clivagens apresentadas - países desenvolvidos, em desenvolvimento e pouco desenvolvidos.

Nos últimos dez anos, o comércio de produtos, bens e serviços através do varejo on-line no site das empresas (empresas de eletroeletrônicos, eletrodomésticos, cosméticos, roupas, assessórios automotivos, livros, entre outros) - o e-commerce - obteve um crescimento exponencial. Entre 2010 e 2015, o e-commerce obteve um crescimento da ordem de 185\%, saindo, em 2010, de US\$ 572 bilhões para US\$ 1,4 trilhão, em 2015, sendo a China responsável por US\$ 562 bilhões, os Estados Unidos por US\$ 349 e o Reino Unido por US\$ 94 bilhões. Esses três países lideram o fluxo do comércio varejista digital no mundo. Não por acaso, as duas principais companhias de e-commerce do mundo, a Amazon (maior empresa em valor de mercado do globo) e a Alibaba (oitava companhia em valor de mercado do mundo), são, respectivamente, norte-americana e chinesa. No Brasil, em 2017, ano de modestíssimo crescimento econômico (1,0\%), o e-commerce obteve um crescimento de $12 \%$, alcançando um faturamento de $\mathrm{R} \$ 60$ bilhões, ao passo que o varejo físico experimentou um recuo de $6 \%$.

O e-commerce foi também potencializado pelo advento da nova economia digital, no interior da qual repousam fenômenos como:

i. a Web 2.0 (fase da Internet ancorada na profusão global das redes sociais digitais, através das quais os usuários, ou engajados digitais, produzem, distribuem e consomem cerca de $75 \%$ de todo o conteúdo digital global);

ii. o big data (compartilhamento de dados e informações acerca dos usuários e consumidores em todo o globo, que tornou dados individuais um dos maiores ativos econômicos contemporâneos; 
iii. a inteligência artificial (incorporação da linguagem e do aprendizado humano em robôs de alta performance computacional, que se automatizam mediante a mimetização e o acúmulo de informação repassada e armazenada por meio da interação com os humanos);

iv. a computação em nuvem (armazenamento de gigantescos bancos de dados em provedores privados conectados on-line, localizados em locais muito distante da maioria dos usuários e armazenados fora dos dispositivos de memórias dos computadores, dos smartphones e demais suportes utilizados pelos usuários);

v. a Internet das coisas (conexão de aparelhos, suportes e objetos através de sensores integrados via Internet).

Nos últimos dez anos esses fenômenos ganharam materialidade comercial e deram forma a novos modelos de negócios. Por exemplo, em 2007 a Amazon lançou o S3, que se tornou o primeiro serviço corporativo de armazenamento de dados na nuvem, embrião da AWS (Amazon Web Services). A AWS se tornou uma das principais empresas da Amazon, tornando-se a líder global de fornecimento de serviços para o armazenamento de dados na computação em nuvem, dominando um terço de todo o mercado e tornando-se, por conseguinte, decisiva para a expansão das redes sociais digitais e dos milhares de startups que surgiram no rastro do processo recente de expansão global da Internet. A AWS se tornou uma gigantesca divisão corporativa da Amazon, prestando serviços exclusivamente para outras empresas, a chamada computação B2B (business to business), como Microsoft, Google e Netflix. Mediante a contratação da AWS, essas empresas dispensam a instalação de parques tecnológicos próprios, a construção e a manutenção de provedores em suas próprias dependências. No primeiro trimestre de 2018, a AWS se tornou uma das divisões mais lucrativas da Amazon. Nesse período, a empresa obteve um faturamento de US\$ 5,1 bilhões e um lucro de US\$ 1,3 bilhão. Nesse mesmo período, as vendas on-line (e-commerce) da Amazon nos Estados Unidos obtiveram um faturamento de US\$ 37 bilhões, extraindo um lucro de US\$ 1,7 bilhão.

Os negócios mencionados acima permitiram o advento da chamada inovação disruptiva, no qual novas plataformas digitais remodelaram por completo muitos mercados globais. A inovação disruptiva está ancorada na criação de plataformas digitais que integram e disponibilizam novas atividades a partir de serviços existentes, catapultando a chamada inovação de serviços. Desse modo, plataformas como a Airbnb modificou por completo a prática de reserva de hospedagem; o Uber modificou a prática de solicitar e utilizar um táxi; o PlayPal alterou a forma de as empresas, os bancos e os consumidores liquidarem suas contas, produtos e serviços; assim 
como o YouTube redefiniu as estratégias publicitárias de produtoras, criadores musicais e anunciantes. A Airbnb, por exemplo, obteve, por meio de sua plataforma, quatro bilhões de reservas em 2014. Nesse mesmo ano, durante a Copa do Mundo no Brasil, $25 \%$ do total de turistas e visitantes que estiveram no país por ocasião do evento ficaram em acomodações intermediadas pelo Airbnb - 150 mil pessoas de um total de 600 que estiveram no Brasil durante o evento esportivo. Como assinala Goodwin, mobilizado por David Rogers,

o Uber, a maior empresa de táxi do mundo, não tem veículos; o Facebook, a mídia mais popular do mundo, não cria conteúdo; o Alibaba, o varejista mais valioso, não tem estoque; a Airbnb, o maior fornecedor de acomodações do mundo, não tem imóveis (Rogers, 2017).

Embora os mercados culturais convencionais integrem o segundo círculo concêntrico da Figura 1, preferimos tratá-lo após a descrição do e-commerce e da nova economia digital para que os contrastes fiquem claros com os serviços culturais-digitais, núcleo da Figura 1 e do nosso interesse analítico e empírico. Os mercados culturais convencionais são compostos por seis agentes estruturais:

i. as empresas culturais privadas especializadas;

ii. as empresas não culturais;

iii. os profissionais criativos especializados e os trabalhadores da cultura;

iv. os bancos comerciais privados;

v. as instituições estatais-governamentais;

vi. os consumidores de bens culturais.

Esses seis agentes apresentam racionalidades econômicas e empresariais distintas, interesses muitas vezes conflitantes e características socioeconômicas também diversas, de acordo com o enraizamento em determinados países (Granovetter, 2018). Os mercados culturais são assim denominados, pois, até há cerca de dez anos, os processos criativos, os modelos de negócios, os critérios de investimento públicos e privados, assim como as práticas de consumo dos conteúdos simbólico-culturais, haviam sido pouco impactados pelo processo de digitalização do simbólico e, por conseguinte, pela construção do capitalismo cultural-digital.

O capitalismo cultural-digital é uma figuração global (Elias, 1993) bastante complexa, poderosa e assimétrica, composta por diversos mercados culturais-digitais 
globais interdependentes e concorrentes entre si. Há três aspectos estruturais que diferenciam os mercados culturais-digitais entre si e os diferenciam dos mercados culturais convencionais:
i. o grau de inovação tecnológica;
ii. o grau de digitalização; e
iii. o grau de convergência digital.

A criatividade é transversal e horizontal aos mercados culturais, perpassa-os e os atravessa; já a presença dos suportes digitais móveis (notadamente os smartphones) e o impacto da Internet 2.0 decorrem do grau e da intensidade dos três aspectos estruturais citados. Os quatro mercados culturais-digitais situados no topo da Figura 2 (musical, audiovisual, editorial e publicitário) são os que detêm o maior grau de inovação tecnológica, o maior grau digitalização e o maior grau de convergência digital. Significa dizer que são os mercados que estão passando por uma intensa transição digital e, por conseguinte, por uma maior penetração dos serviços culturais-digitais. No interior de cada um dos doze mercados culturais apresentados na Figura 2 atuam os mesmos seis agentes estruturais descritos antes:
i. empresas culturais privadas especializadas;
ii. trabalhadores da cultura e profissionais criativos;
iii. empresas não culturais;
iv. bancos comerciais privados;
v. órgãos governamentais e instituições estatais; e
vi. famílias e consumidores de conteúdos artístico-culturais.

No entanto, nos mercados culturais-digitais as empresas culturais são também grandes corporações de tecnologia digital (Google, Amazon, Facebook, Apple e Microsoft - Gafam), que, cada vez mais, financiam, licenciam, distribuem e comercializam conteúdos de arte, cultura e entretenimento.

Quanto mais um mercado cultural convencional apresenta níveis de inovação tecnológica, digitalização e convergência digital, tanto mais ele está ancorado e monetizado pela presença dos serviços culturais-digitais. É o caso do mercado musical, o mercado mais digitalizado do mundo. Em 2014, 46\% de toda a música consumida no planeta já era digital, ficando os conteúdos musicais fruídos por meios de suportes 
FIGURA 2

COMPOSIÇÃO DO CAPITALISMO CULTURAL-DIGITAL:

VARIÁVEIS DO PROCESSO DE DIGITALIZAÇÃO DO SIMBÓLICO

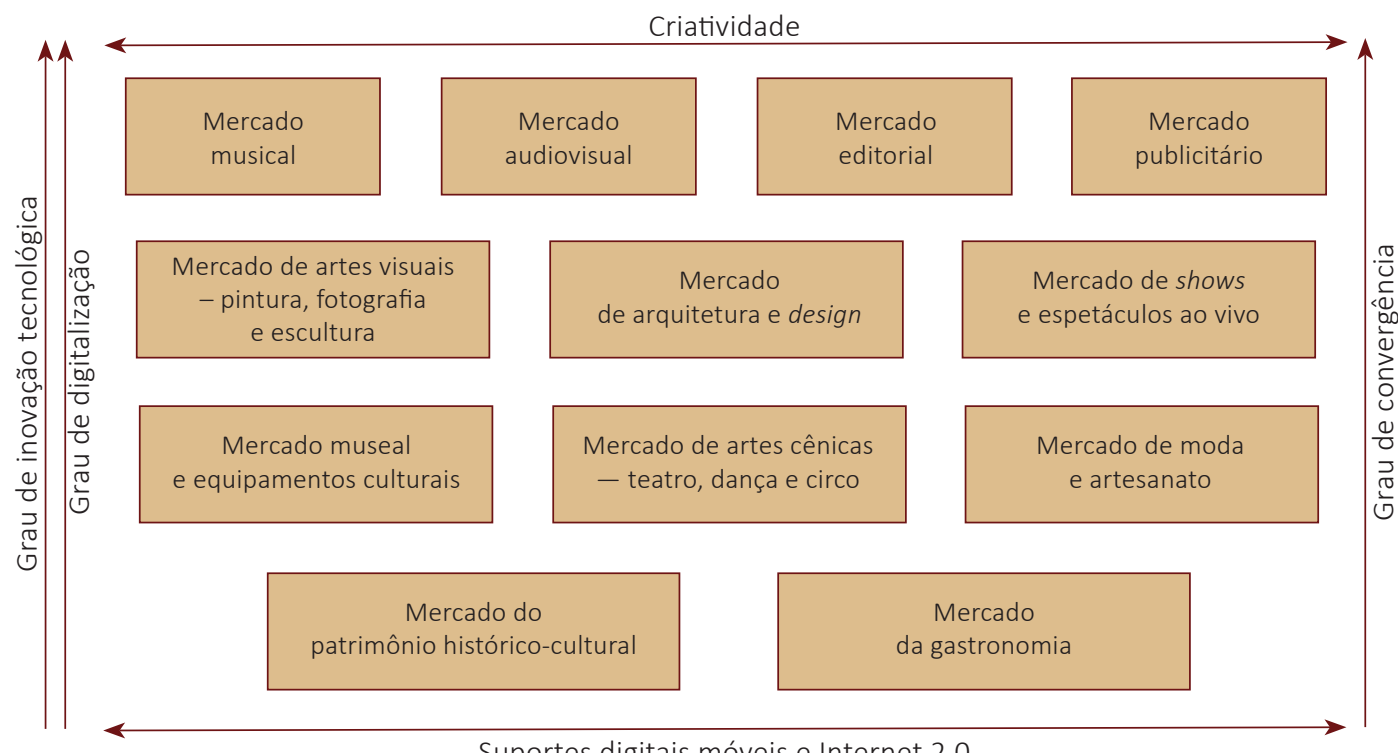

Suportes digitais móveis e Internet 2.0

Fonte: elaboração do autor

físicos com outros 45\% e as performances musicais ao vivo com 9\%. Em 2016, 50\% de todo faturamento do mercado fonográfico global foi gerado pela esfera digital, tendo os suportes físicos (CDs e DVDs) contribuído com 34\% e as performances (shows) ao vivo correspondendo a $14 \%$. Esse mercado passou a contar com a maior presença dos serviços culturais-digitais, especialmente aqueles ofertados através de assinaturas digitais ancorados na tecnologia do streaming, liderados por plataformas como Spotfy, Apple Music e Deezer.

Os serviços culturais-digitais correspondem ao núcleo central do processo de digitalização do simbólico, que é tributário, por sua vez, de quatro fenômenos associados:

i. o intenso processo de aumento da velocidade, de armazenamento e transmissão de dados no âmbito da Internet, materializado na tecnologia do streaming, que somente se tornou possível com o advento da computação em nuvem;

ii. a profusão global dos dispositivos digitais móveis, notadamente os smartphones (em 1990 havia em todo o mundo cerca de 300 milhões de aparelhos celulares, em 2016 esse número foi de 8 bilhões de apa- 
relhos, sendo 5 bilhões de smartphones, cerca de $70 \%$ da população mundial);

iii. a convergência digital, que liga e conecta diversos dispositivos entre si, múltiplos suportes e linguagens, originando o fenômeno transmídia, inteiramente ligado à Internet das coisas; e

iv. o advento da Internet 2.0, fase da Internet na qual a maioria dos dados (textos, notícias, vídeos, músicas, mensagens, imagens etc.), é criada, compartilhada e consumida pelos próprios usuários, conectados e engajados nas principais redes sociais digitais globais, como Facebook, Instagram, WhatsApp, YouTube, Twitter etc. (no início de 2018 o Facebook possuía 2,1 bilhões de usuários).

Esses quatro fenômenos criaram as condições para o fortalecimento das cinco principais corporações globais de tecnologia digital (Google, Apple, Facebook, Amazon e Microsoft - Gafam), e que, agora, também são poderosas financiadoras, compradoras, distribuidoras e comercializadoras de conteúdos de arte, cultura e entretenimento por meio dos múltiplos modelos de negócios, com destaque para a oferta dos serviços culturais-digitais de assinatura via streaming.

O conjunto das exportações do Gafam tornou os Estados Unidos o maior exportador de serviços culturais-digitais do globo, cujo valor total (US\$ 68,6, bilhões em 2013) foi superior ao somatório de todos os 14 maiores exportadores juntos (Unesco, 2015). Podemos ilustrar a diferença entre um bem cultural, que dá vida aos mercados culturais convencionais, e um serviço cultural-digital, que anima os mercados culturais-digitais, da seguinte maneira: a prática de consumo simbólico-cultural de um longa-metragem no cinema diz respeito ao consumo de um bem cultural; já a fruição de uma série ou um longa-metragem numa plataforma digital on-demand, ofertado por empresas como a Netflix, concerne ao consumo de um serviço cultural-digital. Do mesmo modo, a prática de consumo do conteúdo de um show musical refere-se ao consumo de um bem cultural; já a audição desse mesmo conteúdo musical nas plataformas musicais de streaming, como Spotify e Apple Music, transforma-se no consumo de um serviço cultural-digital. A visita ao acervo de um museu concerne à prática de consumo de um bem cultural, essa mesma visita realizada por meio da criação de um perfil digital e/ou um avatar no site do mesmo museu torna-se o consumo de um serviço cultural-digital. A leitura de um livro, em um suporte físico, diz respeito ao consumo de um bem cultural; essa mesma leitura realizada na tela do tablet, do computador, do smartphone e/ ou do suporte de leitura especializado (como o Kindle da Amazon) refere-se a um serviço cultural-digital. 
FIGURA 3

CORPUS EMPÍRICO-CONCEITUAL DO CAPITALISMO CULTURAL-DIGITAL

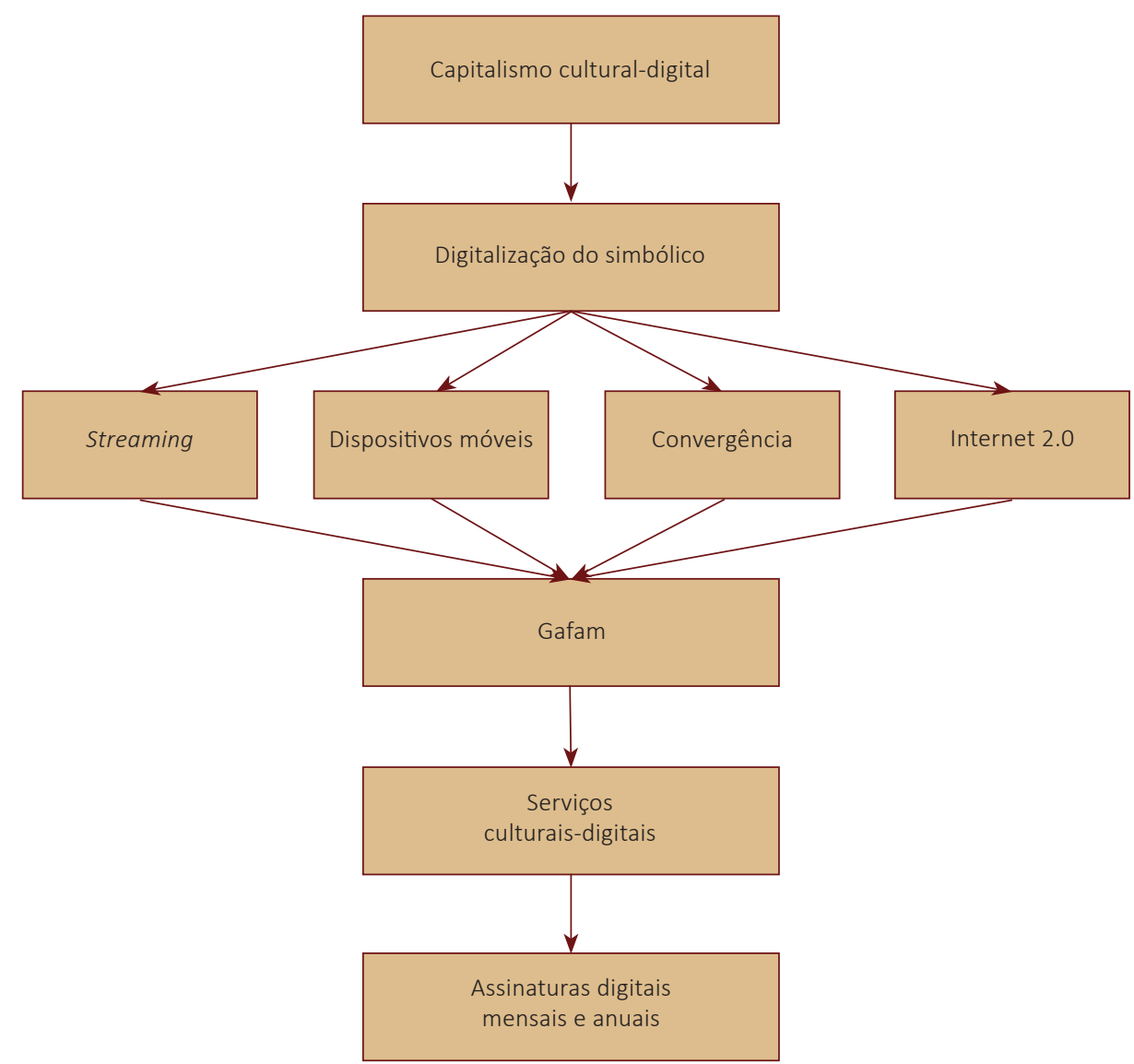

Fonte: elaboração do autor

Os serviços culturais-digitais são serviços que ofertam conteúdos de arte, entretenimento e cultura, por meio de modelos de negócios específicos, desenvolvidos por empresas e plataformas digitais. O consumo dos serviços culturais-digitais também instaura relações de e-commerce, pois, embora não se trate da compra de um objeto físico (eletroeletrônicos, cosméticos e roupas), mas sim da compra de conteúdos musicais, cinematográficos, de games, quadrinhos e outros, essa prática cultural envolve uma operação comercial.

No Brasil, por exemplo, o consumo tanto dos bens culturais como dos serviços culturais-digitais tem aumentado nos últimos dez anos, embora a cesta geral de consumo das famílias tenha sofrido uma forte redução entre 2014 e 2017. De acordo com a pesquisa publicada pela J. Leiva ${ }^{1}$ em 2018, realizada nas 12 capitais brasileiras

1. A pesquisa entrevistou 10.630 pessoas e foi aplicada entre junho e julho de 2017 
mais populosas, as principais práticas de consumo de bens culturais registraram uma elevação. Das 13 práticas pesquisadas (cinemas, leitura, shows, games, festas populares, feiras de artesanato, biblioteca, dança, museu, teatro, circo, sarau e concertos) o destaque maior coube às quatro primeiras. De acordo com a fonte, $64 \%$ dos brasileiros afirmaram terem ido ao cinema pelo menos uma vez nos últimos 12 meses, 55\% responderam que consumiram games, 46\% responderam que foram a shows musicais ao menos uma vez nos últimos 12 meses, 45\% assinalaram que leram ao menos um livro nos 12 meses anteriores a realização da pesquisa, $42 \%$ a festas populares, $40 \%$ a feiras de artesanato e $39 \%$ à biblioteca. Como visto antes, essas práticas culturais integram mercados culturais convencionais, alguns dos quais, como o cinema, a música e os games estão passando por um profundo processo de digitalização. Como será explorado na segunda seção deste trabalho, sustentamos que a expansão das práticas de consumo dos serviços culturais-digitais é muito mais significativa no Brasil e os seus efeitos econômicos muito maiores, em decorrência de quatro aspectos:

\section{i. a intensa expansão da Internet;}

ii. o aumento regular dos smartphones como unidade de consumo de conteúdos de arte, entretenimento e cultura;

iii. a intensidade e a frequência cotidiana desse mesmo consumo, especialmente músicas, filmes, séries, programas de TV e games;

iv. a não necessidade de deslocamento do lar para a fruição dos conteúdos junto aos equipamentos culturais (cinemas, feiras, bibliotecas, museus, galerias, teatros etc.).

Há um feixe de interdependências bastante estreito entre as sociedades pós-industriais de serviços, as economias do conhecimento, o e-commerce, a nova economia digital e os serviços digitais-culturais. Adiciona-se a esse feixe mais uma dimensão: o aumento relativo da renda em diversos países do mundo, o que permitiu - consoante ao barateamento da tecnologia, às políticas públicas de expansão da banda larga e à competição econômica - a expansão geral dos usuários da Internet em todo o globo. No interior desse movimento, intensificado nos últimos dez anos, as maiores corporações globais de tecnologia - o Gafam - decidiram copiar e/ou criar modelos de negócios em torno dos serviços culturais-digitais, reforçando a posição econômica dessas companhias na economia global.

Como evidencia a Tabela 1, a participação predominante do Gafam nos contornos do e-commerce, da nova economia digital e, mais recentemente, nos mercados cul- 
TABELA 1

A CINCO MAIORES EMPRESAS DO MUNDO

(VALOR DE MERCADO - JUNHO DE 2018)

\begin{tabular}{|c|c|c|c|c|c|c|}
\hline Colocação & Empresa & Serviços & $\begin{array}{c}\text { Setor geral de } \\
\text { atuação }\end{array}$ & $\begin{array}{c}\text { Setores } \\
\text { específicos } \\
\text { de atuação }\end{array}$ & Sede & $\begin{array}{c}\text { Valor de } \\
\text { mercado (US\$) }\end{array}$ \\
\hline 10 & Amazon & $\begin{array}{c}\text { Amazon } \\
\text { Marketplace, } \\
\text { Amazon Web } \\
\text { Services (AWS), } \\
\text { Souq.com, Twist, } \\
\text { Amazon Pime } \\
\text { Video }\end{array}$ & $\begin{array}{c}\text { Tecnologia } \\
\text { digital }\end{array}$ & $\begin{array}{c}\text { E-commerce, } \\
\text { nova economia } \\
\text { digital e serviços } \\
\text { culturais-digitais }\end{array}$ & Estados Unidos & 822 bilhões \\
\hline $2 \circ$ & Apple & $\begin{array}{c}\text { Série Iphone, } \\
\text { série Ipad, } \\
\text { sistema opera- } \\
\text { cional IOS, Apple } \\
\text { Music }\end{array}$ & $\begin{array}{l}\text { Tecnologia } \\
\text { digital }\end{array}$ & $\begin{array}{c}\text { E-commerce, } \\
\text { nova economia } \\
\text { digital e serviços } \\
\text { culturais-digitais }\end{array}$ & Estados Unidos & 785 bilhões \\
\hline 30 & Microsoft & $\begin{array}{l}\text { Skype, sistema } \\
\text { Windows, Mixer }\end{array}$ & $\begin{array}{l}\text { Tecnologia } \\
\text { digital }\end{array}$ & $\begin{array}{l}\text { E-commerce, } \\
\text { nova economia } \\
\text { digital e serviços } \\
\text { culturais-digitais }\end{array}$ & Estados Unidos & 725 bilhões \\
\hline 40 & Google & $\begin{array}{c}\text { Sistema de } \\
\text { busca, Chrome, } \\
\text { YouTube, } \\
\text { Android, Google } \\
\text { Maps, Gmail, } \\
\text { Google Drive, } \\
\text { Google Play, } \\
\text { Waze }\end{array}$ & $\begin{array}{l}\text { Tecnologia } \\
\text { digital }\end{array}$ & $\begin{array}{c}\text { E-commerce, } \\
\text { nova economia } \\
\text { digital e serviços } \\
\text { culturais-digitais }\end{array}$ & Estados Unidos & 693 bilhões \\
\hline 50 & Facebook & $\begin{array}{l}\text { WhatsApp, } \\
\text { Instagram, } \\
\text { Messenger }\end{array}$ & $\begin{array}{c}\text { Tecnologia } \\
\text { digital }\end{array}$ & $\begin{array}{l}\text { E-commerce, } \\
\text { nova economia } \\
\text { digital e serviços } \\
\text { culturais-digitais }\end{array}$ & Estados Unidos & 688 bilhões \\
\hline
\end{tabular}

Fonte: Valor Econômico.

turais-digitais, por meio do controle do conteúdo de muitos serviços culturais-digitais, têm resultado em tensões e processos de multa junto a essas companhias. Em julho de 2018, a União Europeia anunciou uma multa de $€$ 4,3 bilhões (aproximadamente R\$ 10,6 bilhões) ao Google. De acordo com a União Europeia, entre 2013 e 2016 o Google forçava os fabricantes de celular a pré-instalar os seus aplicativos (onde consta a Play Store, loja de conteúdos do Google) no sistema operacional desenvolvido pelo próprio Google, o Android, utilizado por cerca de $80 \%$ dos usuários de smartphones em todo o mundo. A União Europeia classifica essa prática como ilegal. A multa imposta ao Google não chega a comprometer as suas reservas e o seu valor de mercado, a primeira da ordem de US\$200 bilhões, a segunda, como demonstra a Tabela 1, avaliada em US\$ 693 bilhões. Importante observar que o valor de mercado leva em conta o valor das ações, as expectativas de crescimento a médio e longo prazo e o domínio de copyright. 
Especialmente no que tange aos serviços culturais-digitais, empresas como Google, Amazon, Facebook, Apple e Microsoft passaram a desenvolver estratégias norteadas pelo sucesso de empresas como a Netflix. Em 2008, a receita da Netflix foi de US\$ 1,4 bilhão, em 2014, seis anos mais tarde, o faturamento saltou para US\$ 5,5 biIhões. Em 2016, o faturamento da empresa foi de US\$ 8,8 bilhões, uma elevação de $60 \%$ em apenas dois anos. No total, $49,43 \%$ desse faturamento foi registrado nos Estados Unidos, e 50,57\% em âmbito internacional. Presente em 190 países, em 2017 na América Latina, a Netflix estava presente principalmente no México (46,8\% dos assinantes da região), no Brasil (31\% dos assinantes na região), e Colômbia (6,6\% do total de assinantes na região). Segundo a Agência Nacional do Cinema (Ancine), estima-se que, em 2017, a Netflix já congregava nove milhões de assinantes no Brasil, o equivalente ao total de assinantes do streaming Grupo Net/Claro, grupo líder no mercado de TV por assinatura no Brasil. A Netflix comercializa no Brasil quatro modalidades de pacotes:

$$
\begin{aligned}
& \text { i. básico (R\$ 19,90); } \\
& \text { ii. padrão (R\$ 27,90); } \\
& \text { iii. premium ( } \mathrm{R} \$ 37,90) \text {; e } \\
& \text { iv. ultra premium }(\mathrm{R} \$ 53,90) \text {. }
\end{aligned}
$$

2. Ver: <https://www. tecmundo.com.br/ mercado/130659netflix-tornaempresa-midiavaliosa-mundo-baterdisney.htm>.

3. Ver: <https:// g1.globo.com/ economia/noticia/ disney-anunciacompra-da-21stcentury-fox.ghtml>.
Em 2017, todos os aparelhos de smartv da Samsung passaram a ser fabricados contendo os aplicativos da Netflix, YouTube e Facebook em seu software. No primeiro semestre de 2016, a Netflix reunia 95 milhões de assinaturas regulares, no segundo semestre de 2018 já eram 120 milhões, contingente que tornou a empresa a mais valiosa companhia de mídia do mundo², com valor de mercado de US\$172 bilhões, ao passo que a Disney - a segunda maior - estava avaliada em US\$ 162 bilhões. A compra da Fox pela Disney ${ }^{3}$, em dezembro de 2017, revela bem a contundência econômica dos serviços culturais-digitais e o grau da concorrência no âmbito dos mercados culturais-digitais. A Disney comprou a Century Fox por US\$ 54,6 bilhões, passando a controlar uma miríade de conteúdos de séries, filmes, documentários e animações, como as séries "Os vingadores" e "X-Men". A operação envolveu a aquisição de 300 canais de TV por assinatura em todo o mundo, além do controle da Endemol Shine Goup, detentores dos direitos de programas como Big Brother e Master Chef. Com a aquisição da Century Fox, a Disney passou a controlar 70\% do principal concorrente direto da Netflix nos Estados Unidos, o serviço de streaming Hulu, que, no final de 2017, já contava com 20 milhões de assinaturas fixas. Com essa aquisição, a Disney anunciou que pretendia oferecer o serviço da Hulu em todo mundo a partir de 2019, passando a concorrer com a Netflix, especialmente por meio da disponibilização para a Hulu da volumosa biblioteca de conteúdos da Dis- 
ney (especialmente animações), como os conteúdos dos estúdios Marvel, também de propriedade da Disney.

Em 2018, a lista de indicados para o prêmio da Academia de Artes e Ciências da Televisão - o Emmy (equivalente ao Oscar) - trouxe diversos conteúdos originais produzidos pela Netflix. A empresa obteve no total 112 indicações, superando canais de TV por assinaturas, como o tradicional HBO. Outros dois serviços de streaming de vídeo também obtiveram indicações, como Amazon Prime Video e Hulu. Em 2014 a principal concorrente direta da Netflix, a Amazon Prime Vídeo (com 60 milhões de assinantes) anunciou um plano de expansão para mais de cem países. Um dos principais aspectos que tornaram o modelo de negócio da Netflix extremamente exitoso e mimetizado foi a criação do mecanismo de análise preditiva ${ }^{4}$.

Como mostra a Tabela 2, há uma miríade de serviços de assinatura de streaming para acesso de conteúdos culturais-digitais em todo mundo. Ancorados em diferentes modelos de negócios, esses serviços extraem distintas formas de monetização e atuam em diferentes mercados culturais-digitais (musical, cinematográfico,

TABELA 2

PRINCIPAIS SERVIÇOS DE STREAMING DO MUNDO

\begin{tabular}{|c|c|c|c|c|}
\hline Empresa & Modelo de negócio & Segmento & $\begin{array}{l}\text { Assinantes, } \\
\text { público }\end{array}$ & Controle \\
\hline Netflix & $\begin{array}{l}\text { Mediante pagamento mensal ou anual, } \\
\text { o assinante tem acesso ilimitado ao } \\
\text { conteúdo do catálogo da empresa. }\end{array}$ & $\begin{array}{l}\text { Séries, filmes, } \\
\text { documentários, } \\
\text { animação e } \\
\text { programas de TV. }\end{array}$ & 120 milhões & Netflix \\
\hline Crunchyroll & $\begin{array}{l}\text { Mediante pagamento mensal ou anual, } \\
\text { o assinante tem acesso ilimitado ao } \\
\text { conteúdo do catálogo da empresa. } \\
\text { Especialista mundial em conteúdos de } \\
\text { anime, mangá, dorama e música. }\end{array}$ & Animação. & 20 milhões & Crunchyroll \\
\hline Crackle & $\begin{array}{l}\text { Mediante pagamento mensal ou anual, } \\
\text { o assinante tem acesso ilimitado ao } \\
\text { conteúdo do catálogo da empresa. } \\
\text { Serviço concorrente do Netflix nos } \\
\text { Estados Unidos. }\end{array}$ & $\begin{array}{l}\text { Séries, filmes e } \\
\text { animação. }\end{array}$ & 11 milhões & Sony \\
\hline Viki & $\begin{array}{l}\text { Mediante pagamento mensal ou anual, } \\
\text { o assinante tem acesso ilimitado ao } \\
\text { conteúdo do catálogo da empresa. } \\
\text { Especializado em conteúdos asiáticos, } \\
\text { especialmente coreanos. }\end{array}$ & Séries e filmes. & Não informado & \\
\hline Popcomflix & $\begin{array}{l}\text { Mediante pagamento mensal, o } \\
\text { assinante tem acesso ilimitado ao } \\
\text { conteúdo do catálogo da empresa. } \\
\text { Especializado em conteúdos } \\
\text { independentes. }\end{array}$ & Filmes. & 6 milhões & $\begin{array}{l}\text { Screen Media } \\
\text { Ventures }\end{array}$ \\
\hline
\end{tabular}

4. O mecanismo consiste em monitorar as ações, as escolhas, os horários, os conteúdos, as faixas etárias, aliando as informações coletadas de acordo com o comportamento dos consumidores, tais como o momento em que o assinante pausa, retorna ou adianta uma determinada cena; quanto tempo após a interrupção da cena o assinante retorna ao conteúdo; em que dia e horários os assinantes mais veem os conteúdos; quais os tipos de dispositivos mais utilizados para acessar os conteúdos: entre outros. No intuito de montar mecanismos de indução para perfis de consumidores, a empresa converte essas informações em dados sistematizados, gerenciados e aplicados por algoritmos que constroem perfil individualizado dos assinantes e sugestões regulares específicas. É por meio desse mecanismo que a empresa decide e define a criação de séries e conteúdos originais. Esse mecanismo também tem sido adotado pelos principais serviços de streaming do mundo. 


\begin{tabular}{|c|c|c|c|c|}
\hline Empresa & Modelo de negócio & Segmento & $\begin{array}{l}\text { Assinantes, } \\
\text { público }\end{array}$ & Controle \\
\hline Looke & $\begin{array}{l}\text { Mediante pagamento mensal, o } \\
\text { assinante tem acesso ilimitado ao } \\
\text { conteúdo do catálogo da empresa. }\end{array}$ & Filmes e séries. & Não informado & Looke \\
\hline $\begin{array}{l}\text { Amazon } \\
\text { Praime Video }\end{array}$ & $\begin{array}{l}\text { Mediante pagamento mensal, o assinan- } \\
\text { te tem acesso ilimitado ao conteúdo do } \\
\text { catálogo da empresa. Um dos principais } \\
\text { concorrentes globais da Netflix. }\end{array}$ & $\begin{array}{l}\text { Filmes, séries e } \\
\text { animações. }\end{array}$ & 60 milhões & Amazon \\
\hline Twitch & $\begin{array}{l}\text { Mediante pagamento mensal, o } \\
\text { assinante tem acesso ilimitado ao } \\
\text { conteúdo do catálogo da empresa. } \\
\text { Líder mundial na transmissão de jogos e } \\
\text { partidas de games. }\end{array}$ & Games. & 20 milhões & Amazon \\
\hline $\begin{array}{l}\text { Google Play e } \\
\text { Google Play } \\
\text { Música }\end{array}$ & $\begin{array}{l}\text { Assinatura gratuita com pagamento } \\
\text { a la carte, por compra ou aluguel, } \\
\text { para assistir e/ou ouvir um conteúdo } \\
\text { específico. }\end{array}$ & $\begin{array}{l}\text { Música, séries e } \\
\text { filmes. }\end{array}$ & 12 milhões & Google \\
\hline YouTube & $\begin{array}{l}\text { Conteúdo gratuito fornecido aos } \\
\text { espectadores, as receitas advêm da } \\
\text { publicidade. Ao invés dos anunciantes } \\
\text { pagarem pelo acesso são os anunciantes } \\
\text { quem monetizam o negócio, em geral, } \\
\text { a cada mil acessos. O conteúdo é } \\
\text { gerado pelos próprios usuários. Maior } \\
\text { plataforma de vídeos do mundo. }\end{array}$ & Audiovisual geral. & $\begin{array}{l}2,5 \text { bilhões de } \\
\text { espectadores } \\
\text { por dia ( } 35 \% \text { da } \\
\text { humanidade) }\end{array}$ & Google \\
\hline $\begin{array}{l}\text { YouTube } \\
\text { Graming }\end{array}$ & $\begin{array}{l}\text { Serviço especializado em games. } \\
\text { Transmissão de jogos e partidas de } \\
\text { games. }\end{array}$ & Games. & Não informado & Google \\
\hline Mixer & $\begin{array}{l}\text { Serviços especializados para transmissão } \\
\text { de partidas e jogos digitais para o } \\
\text { console Xbox One. }\end{array}$ & Games. & 10 milhões & Microsoft \\
\hline Spotify & $\begin{array}{l}\text { Serviço especializado em música. Líder } \\
\text { global de conteúdos musicais. }\end{array}$ & Música. & 70 milhões & Spotify \\
\hline Deezer & Serviço especializado em música. & Música. & 7 milhões & Deezer \\
\hline Apple Music & Serviço especializado em música. & Música. & 27 milhões & Apple \\
\hline Pandora & $\begin{array}{l}\text { Serviço especializado em música através } \\
\text { de rádios on-line. }\end{array}$ & Música. & Não informado & Apple \\
\hline Social Comics & $\begin{array}{l}\text { Serviço especializado em conteúdos de } \\
\text { quadrinhos - HQ. }\end{array}$ & Quadrinhos. & 5 milhões & Social Comics \\
\hline Me Salva & $\begin{array}{l}\text { Serviço especializado em conteúdos } \\
\text { educacionais preparatórios para o Enem } \\
\text { e concursos públicos. }\end{array}$ & $\begin{array}{l}\text { Conteúdos } \\
\text { educacionais. }\end{array}$ & Não informado & Não informado \\
\hline Hulu & Serviço especializado em filmes e séries. & Filmes e séries. & 20 milhões & Disney \\
\hline Vimeo Live & $\begin{array}{l}\text { Conteúdo gratuito fornecido aos } \\
\text { espectadores, as receitas advêm da } \\
\text { publicidade. Ao invés dos anunciantes } \\
\text { pagarem pelo acesso são os anunciantes } \\
\text { quem monetizam o negócio. Conteúdos } \\
\text { gerados pelos próprios usuários. }\end{array}$ & Audiovisual. & Não informado & Vimeo \\
\hline
\end{tabular}

Fonte: Ancine, 2018. 
de séries, games, animação, quadrinhos etc.). Dos 20 serviços arrolados na Tabela 2, sete pertencem ao Gafam. Embora pareça pouco, algumas dessas corporações já lideram muitos dos mercados culturais-digitais. Por exemplo, embora a Netflix lidere com folga o serviço de streaming de séries, filmes, documentários e programas televisivos, o serviço da Amazon Prime Vídeo tem crescido de modo rápido em todo o mundo, alcançando 60 milhões de assinantes. Além disso, o Twitch - serviço de assinatura de streaming de games da Amazon - é líder absoluto nesse ecossistema específico do vetor games, justamente o ecossistema que mais cresce no mundo, o digital. Em seguida, com seu modelo de negócio específico, vem o YouTube Graming, também especializado na transmissão de games on-line. Controlado pelo Google, o YouTube é a maior plataforma audiovisual do planeta, está presente em 88 países, 77 idiomas, tem uma audiência diária de 2,5 bilhões de pessoas, que assistem, em média, 4 bilhões de vídeos por dia. A Apple Musica já é o segundo serviço de streaming de música mais utilizado do planeta, com 27 milhões de assinantes, superado apenas pelo Spotify, com 70 milhões. Nesse mesmo diapasão, poderíamos citar ainda os serviços de streaming do Google (Google Play e Google Play Música) e da Microsoft.

\section{A expansão dos serviços culturais-digitais no Brasil}

Nos últimos dez anos, o Brasil vive uma forte expansão do contingente de usuários de Internet e, com efeito, o país tem experimentado uma intensa expansão dos serviços culturais-digitais, com destaque para os serviços de assinatura digital ancorado na tecnologia do streaming. Essa expansão tem sido marcada por três aspectos:

i. uma profunda assimetria entre as clivagens de renda, escolaridade, faixa etária e região;

ii. a ampliação geral do acesso aos conteúdos artísticos, culturais e de entretenimento por meio dos dispositivos digitais móveis, especialmente os smartphones;

iii. uma a elevação paulatina do acesso e do consumo dos estratos mais pobres à Internet.

De acordo com o Comitê Gestor de Internet no Brasil (CGI-BR), em 2016, o Brasil possuía 54\% dos seus domicílios com acesso regular à Internet. Significa que 61\% da população brasileira com dez ou mais anos de idade estão conectados à Internet, o que revela um contingente total de 125 milhões de brasileiros com acesso 
5. Pesquisa realizada pela Secretaria de Comunicação da Presidência da Republica (Secom$P R)$. à rede. Em 2008, do total de usuários da Internet no Brasil, 53\% acessavam a rede todos os dias ou quase todos os dias. Oito anos depois, em 2016, do total de usuários (125 milhões), 86\% acessaram a rede todos os dias ou quase todos os dias, um crescimento de $40 \%$. De acordo com a pesquisa "Tempo livre e consumo de mídia no Brasil”5, em 2017, 80\% do estrato domiciliar com maior renda (acima de $\mathrm{R} \$ 17.600$ por mês) acessou a Internet todos os dias, ao passo que $61 \%$ dos domicílios com menor renda (até R\$ 880) não acessaram nenhum dia. Já 77\% do estrato intermediário (com renda mensal entre $\mathrm{R} \$ 4.400$ e $\mathrm{R} \$ \mathbf{8 . 8 0 0}$ ) acessou a Internet todos os dias da semana.

No que tange aos critérios regionais, o Sudeste concentra a grande maioria dos usuários de Internet no Brasil, $69 \%$ de sua população está conectada, seguido pelo Centro-Oeste com 63\%, o Sul com 60\%, o Norte com 60\% e o Nordeste com 50\%. Embora as assimetrias de renda e regionais sejam bastante acentuadas, nos últimos cinco anos registrou-se uma elevação paulatina do acesso dos estratos mais pobres. De acordo com a Síntese dos indicadores sociais no Brasil, do IBGE, 46\% da população brasileira localizada abaixo da linha da pobreza tem acesso à Internet por meio de dispositivos digitais móveis, principalmente o smartphone. O IBGE utiliza como critério para mensuração dos agregados situados abaixo da linha da pobreza a métrica utilizada pelas Nações Unidas (ONU) e o Banco Mundial, qual seja, domicílios (famílias) que recebem por dia US\$ 5,50. De acordo com a cotação do dólar em juIho de 2018, esse valor correspondia a $R \$ 21,00$, o que totaliza $R \$ 630,00$ mensais. De acordo com esse critério, em 2016, 52 milhões de brasileiros estavam abaixo da linha da pobreza, aproximadamente a quarta parte da população brasileira. Dessa população, conforme o IBGE, 46\% possuíam acesso à Internet por meios dos dispositivos móveis, o que significa que 24 milhões de brasileiros abaixo da linha da pobreza têm acesso regular à Internet através desses dispositivos. O Gráfico 1 revela, de modo mais desagregado, esse fenômeno.

Como se observa, foram nos três estratos mais pobres que o uso da Internet se ampliou entre 2013 e 2015. No estrato com domicílios que recebem entre zero e um quarto de salário mínimo ( $R$ \$ 238,50 em valores de 2018) o aumento foi de $37 \%$ entre 2013 e 2015. Já no estrato com renda domiciliar entre mais de um quarto e meio salário mínio ( $R \$ 477,00$ em valores de 2018) o crescimento foi de 35,5\%. No estrato seguinte, com renda familiar localizada entre meio e um salário mínimo (R\$ 954 em valores de 2018) o crescimento foi de 30\%. Por fim, no estrato de renda domiciliar entre um e dois salários mínimo o crescimento foi de apenas $4 \%$. No estrato com maior renda familiar, que recebe mais de dez salários mínimos ( $\mathrm{R} \$ 9.540,00$ em valores de 2018), o crescimento foi de apenas $2,5 \%$. Certamente o crescimento do 


\section{GRÁFICO 1}

Percentual de Pessoas que utilizam a INTERnet, No PERÍOdo de REFERÊNCIA DOS ÚLTIMOS TRÊS MESES, NA POPULAÇÃO DE 10 ANOS OU MAIS DE IDADE POR CLASSE DE RENDIMENTO MENSAL DOMICILIAR PER CAPITA (BRASIL, 2013-2015)

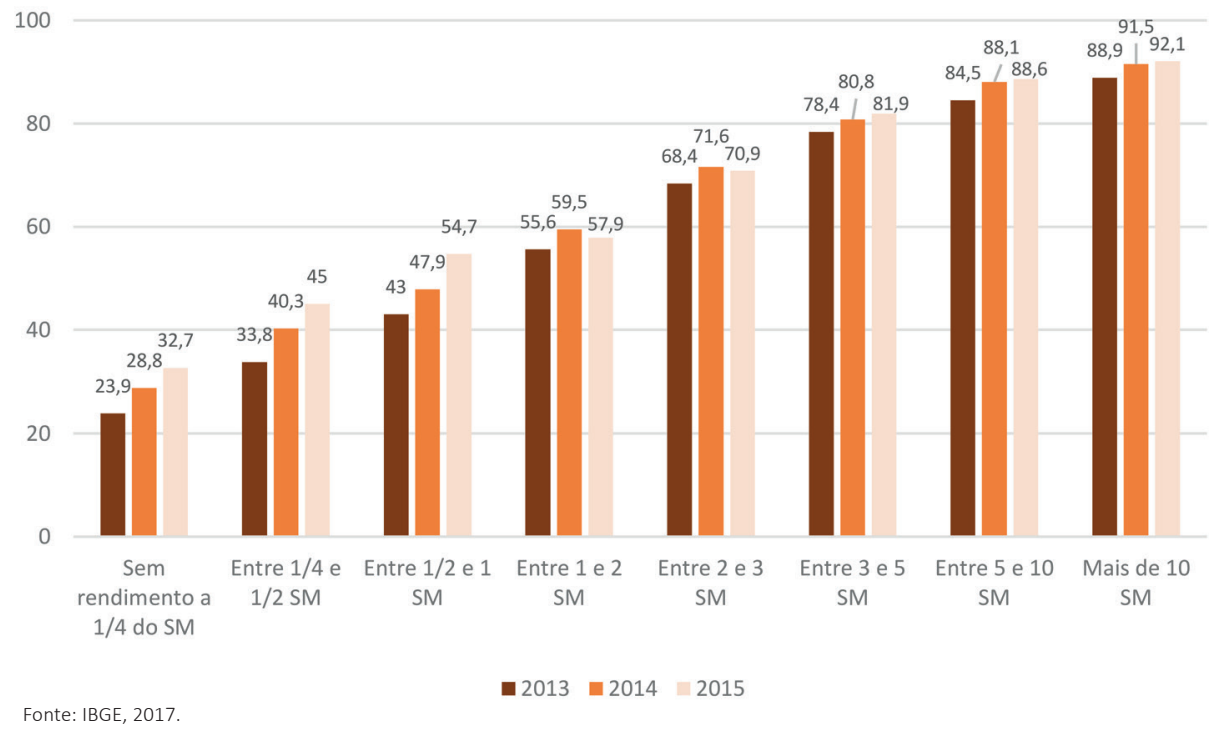

acesso à Internet por parte dos contingentes mais pobres ocorreu por dois fatores principais:

i. expansão das políticas públicas de banda larga e universalização relativa do Wifi;

ii. aumento do interesse pelas redes sociais digitais, notadamente Facebook, WhatsApp e YouTube.

Do total de usuários que acessaram a Internet em 2016, 93\% realizavam o acesso por meio de smartphones. Desses, $86 \%$ utilizaram redes de WiFi para acessar a Internet, ao passo que outros $70 \%$ utilizaram a rede $3 G$ e 4 G. Salta aos olhos o crescimento de usuários de pacotes de telefonia pós-pagos, muito mais utilizados pelos agregados com renda superior, e que são os pacotes que permitem o uso da tecnologia $3 G$ e $4 G$ para o consumo mais prolongado de serviços culturais-digitais, especialmente os serviços de assinatura por streaming (filmes, séries, músicas, games etc.). Em 2008, apenas 8\% do total de usuários que acessaram a Internet por meio do smartphone optaram por planos pós-pagos junto as principais operadoras de telefonia celular móvel (TIM, OI, Vivo e Claro). Em 2016, passados oito anos, esse percentual subiu para $23 \%$, crescimento de quase $187,5 \%$. 
GRÁFICO 2

PeRCENTUAL de DOMICÍlIOS COM A UTILIZAÇÃO DA INTERNET, SEGUNDO O TIPO DE EQUIPAMENTO PARA O ACESSO (BRASIL, 2013/2015)

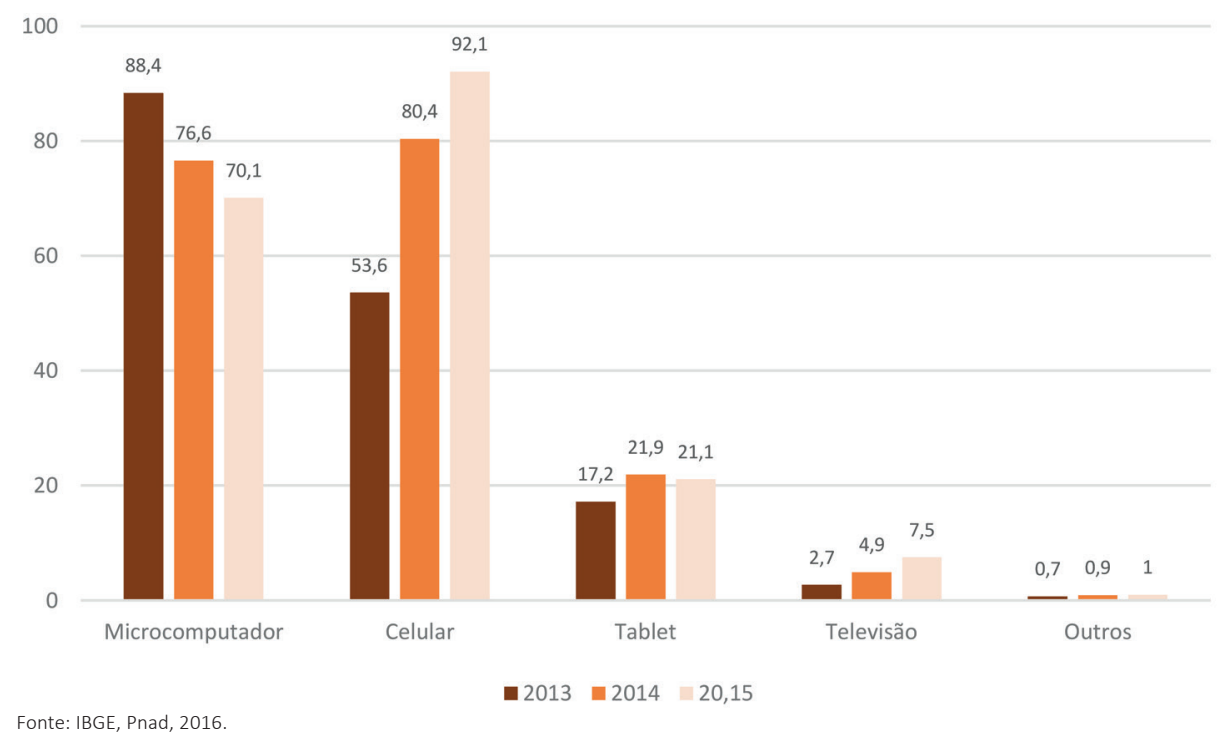

O Gráfico 2 revela um intenso crescimento no uso dos smartphones para acessar a Internet no Brasil. Entre 2013 e 2015, o crescimento foi de 71,8\% em apenas dois anos. Por conseguinte, aumentou também o consumo de conteúdos de arte, cultura e entretenimento por meio dos smartphones. De acordo com CGI-BR, em 2014, 58\% dos usuários de smartphones assistiram filmes, séries, vídeos, músicas e programas através dos serviços de streaming, em 2015 esse percentual subiu para 64\%. Do mesmo modo, em 2014, 57\% desses mesmos usuários ouviram músicas por meio dos serviços de streaming, ao passo que, no ano seguinte, esse percentual foi a 59\%. Por outro lado, os serviços de download sofreram um recuo. Em 2014, 29\% baixaram filmes por meio de download, no ano seguinte esse percentual foi de $23 \%$. No que tange à música, em 2014, 51\% baixaram conteúdos musicais por meio do download, caindo para $48 \%$ no ano seguinte.

Como se observa, a tecnologia do streaming, por meio do aumento da velocidade do armazenamento de dados na computação em nuvem, permite a transmissão e o consumo instantâneos on-line de filmes, séries, documentários, programas de TV, games, músicas, entre outros, resultando em modelos de negócios específicos. Diferente, com efeito, do download, que exige uma unidade de tempo maior para que o conteúdo seja descarregado ou "baixado". De acordo com o IBGE, em 2015, 88\% dos usuários de smartphones utilizaram a Internet para acessar as redes sociais di- 
gitais (Facebook, Instagram, WhatsApp, Skype etc.); 53\% utilizaram os smartphones para consumir vídeos, programas, séries e filmes em serviços on-line como Netflix e YouTube; e outros 47\% utilizaram o smartphone para ouvir música nos serviços on-line como Spotify, Apple Music, Deezer e YouTube (IBGE/Pnad/Tics, 2017). As séries históricas realizadas pelo CGI-BR revelam um crescimento ainda maior. O intervalo entre 2014 e 2016 captura muito bem essa expansão. Em 2014, 57\% dos usuários de smartphones ouviram música, esse percentual aumentou para 66\% em 2016. Seguindo esse diapasão, em 2014, 42\% assistiram vídeos, dois anos depois esse percentual alcançou $62 \%$, um crescimento de quase $50 \%$.

Os dados apresentados podem ser corroborados pela expansão da Netflix no Brasil. A Netflix chegou no país em 2012, e, desde então, não parou de crescer. Como assinala a Ancine, estima-se que a empresa já possua nove milhões de assinantes no Brasil. Como a senha de acesso ao serviço é compartilhada por mais de uma pessoa (filhos, cônjuges, namorados, amigos etc.), estima-se que cerca de 20 milhões de pessoas já tenham acesso ao serviço, fato que torna o Brasil o terceiro maior mercado mundial da empresa, sendo os Estados Unidos e o Canadá o primeiro e o segundo, respectivamente. De acordo com a pesquisa Panorama Mobile Time/ Opnion Box, a Netflix é o serviço de streaming com a maior penetração no Brasil, com presença de $32 \%$ entre os usuários de smartphones que pagam assinaturas regularmente. Significa que, no que tange aos smartphones, se $24 \%$ do total dos indivíduos que acessam regularmente a Internet no Brasil o fazem por meio dos smartphones com pacotes pós-pagos, tem-se então o contingente de 30 milhões. Desses, 32\% assinam e pagam a Netflix. Logo, temos então no Brasil o contingente de 9,6 milhões de usuários de smartphones com pacotes de telefonia pós-pagos que dispõem do aplicativo da Netflix em seus aparelhos celulares - dado que coincide com a estimativa divulgada pela Ancine.

Mediante os dados arrolados, é possível constatar que as quatro dimensões do processo de digitalização do simbólico (tecnologia de streaming, expansão do uso dos dispositivos digitais móveis, a convergência digital e a consolidação da Web 2.0) penetraram com intensidade no Brasil, resultando na expansão dos serviços culturais digitais, especialmente dos serviços de assinatura de conteúdos musicais, séries, filmes e games. Nos últimos cinco anos esse fenômeno teve dois impactos imediatos:

i. a estruturação jurídica e financeira da principal política pública de cunho econômico-cultural existente no Brasil contemporâneo, o Fundo Setorial do Audiovisual (FSA);

ii. a mudança nos gastos orçamentares das famílias brasileiras com bens e serviços culturais. 
O Fundo Setorial do Audiovisual (FSA) foi criado em 2006, instituído como modalidade especifica do Fundo Nacional de Cultura (FNC). O FSA foi criado para dinamizar a cadeia produtiva dos conteúdos audiovisuais brasileiros - longas-metragens, séries, telefilmes, animação e games. Até 2011 o FSA obteve pouco impacto econômico no mercado de conteúdos audiovisuais brasileiros. Até esse último ano, duas modalidades de tributos destinavam recursos para o FSA, a Contribuição para o Desenvolvimento da Indústria Cinematográfica Brasileira a partir das remessas (Codecine Remessa) e a Contribuição para o Desenvolvimento da Indústria Cinematográfica Brasileira a partir do número de títulos (Codecine Títulos). Somados, até 2011, esses dois tributos não destinaram recursos suficientes para impactar o mercado de conteúdos audiovisuais brasileiros.

O mercado de audiovisual é o maior mercado cultural convencional do mundo, composto por seis vetores:

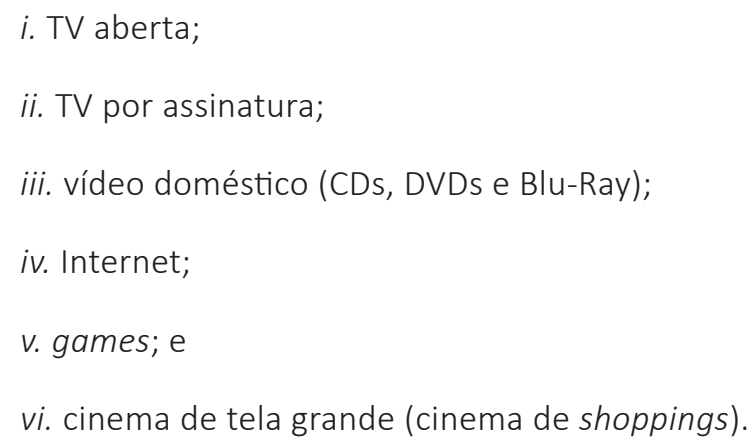

O mercado de conteúdo audiovisual brasileiro é composto pelos mesmos seis vetores, no interior dos quais predominam os conteúdos brasileiros, criados, produzidos, distribuídos e consumidos pelo/no Brasil. A partir de 2011, com a aprovação da Lei n.⒓485 (nova Lei da TV por assinatura), esses conteúdos experimentaram um grande crescimento. A referida lei criou um novo imposto, o Codecine Teles, que passou a ser devida pelos prestadores de serviços que se utilizem de meios que possam distribuir conteúdos audiovisuais, tais como as empresas de telecomunicações (Ancine, 2013). Com isso, as grandes operadoras de telefonia móvel e fixa que atuam no Brasil (TIM, OI, Vivo e Claro) passaram a pagar regularmente a Codecine Teles.

Como foi observado anteriormente, o mercado audiovisual global convencional tem passado por uma forte digitalização do simbólico. Por meio dos dados mobilizados, esse processo tem ocorrido no Brasil com maior vigor nos últimos cinco anos. O intenso aumento do consumo de conteúdos audiovisuais (especialmente séries, fil- 
mes e músicas) pelos smartphones junto aos diferentes planos ofertados pelas operadoras de telefonia móvel resultou num crescimento avassalador do fluxo audiovisual através dos celulares. Esse aspecto fez crescer sobremaneira a arrecadação do Codecine Teles e, com isso, os recursos financeiros destinados para o FSA. Esse aspecto modificou todos os elos (produção, distribuição, exibição e consumo) do mercado de conteúdo audiovisuais brasileiros, pois o FSA passou a destinar recurso para o fortalecimento das empresas que atuam nesses elos.

Em 2012, primeiro ano de funcionamento pleno da Lei n.ํ 12.485 e, por conseguinte, da nova modalidade de tributação - a Codecine Teles -, o FSA teve à sua disposição R\$ 725 milhões, dos quais R\$ 655 milhões foram decorrentes da arrecadação da Codecine Teles, ou seja, 92\% de todos os recursos do FSA. Em 2015, com o aumento do fluxo de conteúdos digitais via smartphones, o volume de arrecadação do FSA chegou a RS 1,1 bilhão, dos quais 90\% decorrentes da arrecadação da Codecine Teles. Esses recursos foram destinados ao principal gestor financeiro do FSA, o Banco Nacional de Desenvolvimento Econômico e Social (BNDES), e, com efeito, emprestado, a juros bastante módicos, às empresas brasileiras especializadas na criação, produção, distribuição e exibição de conteúdos audiovisuais brasileiros. Em 2012, primeiro ano de funcionamento pleno do FSA, foram produzidos 83 longas-metragens nacionais; quatro anos mais tarde, em 2016, foram 142, crescimento de $70 \%$ em apenas quatro anos. Em 2009, 61,9\% dos títulos brasileiros (principalmente longas metragens) foram distribuídos por empresas com origem e sede do capital localizada no exterior, principalmente os principais estúdios de produção e distribuição norte-americanos. Em 2015, seis anos depois, apenas 7\% dos títulos nacionais foram distribuídos por empresas sediadas no exterior, 93\% dos títulos nacionais foram distribuídos por empresas brasileiras.

Esse conjunto de políticas para o setor contribuiu para que os longas-metragens brasileiros enfrentassem parte da concorrência dos longas-metragens norte-americanos. Mesmo com a severa recessão econômica ocorrida em 2015 e 2016, acompanhada de uma forte redução do consumo das famílias brasileiras (redução de 3,2\% em 2014 e 4,3\% em 2016)(IBGE, 2017), o total de consumidores nas salas de cinema no Brasil obteve uma forte elevação na série histórica entre 2010 e 2017. Saindo, em 2010, de 134,8 milhões de ingressos vendidos para 181,2 milhões de ingressos, em 2017; sendo que, de 2015 para 2016, auge da recessão no Brasil, o crescimento foi de 6,5\%, saindo de 173 milhões de ingressos para 184,3 milhões. Mesmo diante desse fator e, principalmente, em face da decisiva atuação do FSA, a participação de mercado (market share) dos longas-metragens brasileiros oscilou, chegando a 19,1\% (25,7 milhões de ingressos vendidos) em 2010, recuando para 10,7\% (15,7 milhões de ingressos) em 2012, voltando a subir para 16,5\% (30,4 
milhões de ingressos) em 2015, voltando novamente a recuar para 9,6\% (17,4 miIhões de ingressos) em 2016. Mesmo em face de tais oscilações, resultado da voraz competição global pelo controle da produção, distribuição e exibição de conteúdos cinematográficos, é possível sustentar, sem embargo, que o mercado de conteúdos audiovisuais brasileiro hoje - nos seus seis vetores - é financiado pela expansão dos serviços culturais-digitais no país e, por conseguinte, pelo processo de rápida digitalização do simbólico.

Não há dúvida de que esses aspectos exigem uma reformulação na metodologia do cálculo utilizado para mensurar a média de gastos com bens e serviços culturais por parte das famílias brasileiras e, por conseguinte, no cômputo geral do PIB da cultura no Brasil. De acordo com a Pesquisa de Orçamento Familiar do IBGE (POF/IBGE), em 2003, as famílias brasileiras gastaram, em média, 3,5\% do seu orçamento com bens culturais (cinema, teatro, livros, museus, shows etc.), que compunham os mercados culturais convencionais. Em 2009, de acordo com essa mesma fonte, a média dos gastos familiares com cultura se elevou para $5 \%$. Conforme a POF/IBGE, caso os serviços com telefonia (móvel e fixa) fossem adicionados à rubrica cultura, a média dos gastos das famílias brasileiras saltaria para $8,4 \%$.

Em 2003 e 2009 não havia necessidade metodológica de inserção dos gastos com telefonia (móvel e fixa) na rubrica geral cultura, algo que se tornou absolutamente necessário, especialmente pelo fato de que o smartphone se tornou uma unidade de criação, produção, distribuição e, principalmente, de consumo de conteúdos de arte, cultura e entretenimento. Desse modo, sustentamos ser imprescindível que as métricas e variáveis utilizadas para o cálculo da média dos gastos com cultura por parte das famílias brasileiras incorporem os serviços culturais-digitais na composição dos gastos familiares com cultura. Essa inserção alteraria por completo a composição do cálculo do PIB da cultura no Brasil, que não leva em conta as variáveis clássicas de composição do PIB de demanda (a mais utilizada em todo o mundo):

\author{
i. consumo das famílias; \\ ii. consumo do governo; \\ iii. investimento das empresas; e \\ iv. relação entre exportação e importação (Alves, 2016).
}




\section{Considerações finais}

Iniciamos este trabalho com a seguinte indagação: como e por que as principais corporações de tecnologia digital do mundo (Google, Amazon, Facebook, Apple e Microsoft - Gafam) também têm se tornado as principais empresas de arte, entretenimento e cultura e como esse processo vem ocorrendo no Brasil?

O Brasil, como diversos países do mundo, mediante a digitalização de seus mercados culturais convencionais, tem abrigado um capitalismo cultural-digital que se expande e se consolida no âmbito de uma estrutura de assimetrias bastante acentuada - de renda, escolaridade e região -, potencializando profundas desigualdades nas práticas de consumo dos serviços-culturais digitais. No entanto, o paulatino acesso dos estratos mais pobres à Internet, especialmente por meio dos smartphones, revela como tem sido intenso o processo de digitalização do simbólico em alguns mercados culturais convencionais no Brasil, como o audiovisual (série, filmes e programas de TV), o musical e o de games, tornando-os, cada vez mais, mercados culturais-digitais. Esse fenômeno revela o quanto o Brasil tem se tornado estratégico para as corporações de tecnologia digital, que também têm se tornado parte das principais corporações produtoras, controladoras, distribuidoras e comercializadoras de conteúdos de arte, cultura e entretenimento em todo o mundo.

Esses aspectos conjugados conferem ainda mais fecundidade analítica às categorias de capitalismo cultural-digital e digitalização do simbólico. No entanto, como deixamos evidenciado, o uso analítico e interpretativo da primeira busca distanciar-se e despojar-se de qualquer totalidade que abriga uma intencionalidade teleológica. Não significa, todavia, que tais corporações não tenham e não pratiquem interesses econômicos e comerciais, antes o contrário, elas os têm. Boa parte da descrição, dos dados mobilizados e da interpretação cunhada consistiu em apresentar tais interesses, materializados em modelos de negócios - os serviços culturais, especialmente os serviços de assinaturas via streaming. No entanto, no decorrer dos últimos dez anos, a intensidade e intercorrência com que os modelos de negócios, as estratégias e decisões foram construídas revelam muito mais a construção processual de um arranjo de interdependências tensas e conflitantes entre corporações e muito menos totalidades marcadas por intencionalidades sistêmicas que alcançam os fins previamente estabelecidos. Desse modo, buscamos restituir categorias empíricas e analíticas caras à sociologia econômica, como mercado, capitalismo, modelo de negócio, empresas, tecnologia e racionalidade empresarial, aproximando-as de uma visada mais descritiva e construtivista. 


\section{Referências}

ADORNO, Teodor; HORKEIMER, Max. Dialética do esclarecimento. Rio de Janeiro: Jorge Zahar, 2000.

AGÊNCIA NACIONAL DE CINEMA (ANCINE). Relatório Anual de Gestão do Fundo Setorial do Audiovisual - Exercício 2016. Rio de Janeiro: Ancine, 2017.

ALVES, Elder P. Maia. A expansão do mercado de conteúdos audiovisuais brasileiros: a centralidade dos agentes estatais de mercado - o FSA, a Ancine e o BNDES. Caderno CRH - Ufba P (impresso), v. 30, p. 477-494, 2016.

BELL, Daniel. The coming post-industrial society. New York: Basic Books, 1973.

BENJAMIN, Walter. A obra de arte na época de sua reprodutibilidade técnica. In: BENJAMIN, Walter. Benjamin, Coleção "Os Pensadores". São Paulo, Abril Cultural, 1980.

BOURDIEU, Pierre. As estruturas sociais da economia. Lisboa: Instituto Piaget, 2001.

CANCLINI, Néstor Garcia. Culturas híbridas. São Paulo: EdUSP, 2001.

CASTELS, Manuel. A era da informação: a sociedade em rede. São Paulo: Paz e terra, 2009.

COMITÊ GESTOR DE INTERNET NO BRASIL. Pesquisa sobre os usos das tecnologias de informação e comunicação nos domicílios brasileiros - Tic domicílios. São Paulo: CGIB, 2017.

ELIAS, Norbert. O processo civilizador, v. I e II. Rio de Janeiro: Zahar, 1993.

GRANOVETTER, Mark. The sociology of economics life. Montreal: Kobo Editions, 2018.

INSTITUTO BRASILEIRO DE GEOGRAFIA E ESTATÍsTICA (IBGE). Síntese dos indicadores sociais: uma análise das condições de vida da população brasileira. Rio de Janeiro: IBGE, 2017.

- Acesso à Internet e à televisão e posse de telefone móvel celular para uso pessoal 2015. Rio de Janeiro: IBGE, 2016.

JENKINS, Henry. Cultura da conexão: criando valor e significado por meio da mídia propagável. São Paulo: Aleph, 2014.

J. LEIVA. Cultura na cidade. São Paulo: J. Leiva, 2018. 
LEMOS, André. Cibercultura: tecnologia e vida social na cultura contemporânea. Porto Alegre: Sulina, 2002.

MARTEL, Frederic. Smart: o que você não sabe sobre a Internet. Rio de Janeiro: Civilização Brasileira, 2015.

MARTINHO, Luís Mauro Sá. Teoria das mídias digitais: linguagens, ambientes e redes. Petrópolis: Vozes, 2017.

ROGERS, David L. Transformação digital: repensando o seu negócio para a era digital. São Paulo: Autêntica Business, 2017.

SECRETARIA DE COMUNICAÇÃO SOCIAL DA PRESIDÊNCIA DA REPÚBLICA. Pesquisa brasileira de mídia. Brasília: Presidência da República, 2016.

SILVA, Ruana Maíra Alves Rufino. Panorama do VoD no Brasil. Perspectiva do VoD no Brasil e no mundo. Rio de Janeiro: Ancine, 2018.

TUERCHI, Lenita Maria; MORAIS, José Mauro. Políticas de apoio à inovação tecnológica no Brasil: avanços recentes, limitações e propostas de ação. Brasília: Ipea, 2016.

ORGANIZAÇÃO DAS NAÇÕES UNIDAS PARA A EDUCAÇÃO, A CIÊNCIA E A CULTURA (UNESCO). Cultural times. The first global map of cultural and creative industries. Paris: Unesco, 2015

WEBER, Max. Economia e sociedade, v. I e II. Brasília: EdUnB, 1994.

WHITE, Andrew. Mídia digital e sociedade: transformando política, economia e práticas sociais. São Paulo: Saraiva, 2017.

WOLFF, Michael. A televisão é a nova televisão: a velha mídia na era digital. São Paulo: Globo, 2015. 